\title{
DNA Barcoding revealing the occurrence of Isarachnanthus (Cnidaria; Anthozoa; Ceriantharia) in Cape Verde
}

\author{
Sérgio Nascimento Stampar ${ }^{1,4}$; Celine S.S. Lopes ${ }^{1,5}$; Stefany Archangelo de Angelis ${ }^{1,6}$ \& André Carrara Morandini ${ }^{2,3,7}$ \\ 1 Universidade Estadual Paulista (UNESP), Faculdade de Ciências e Letras, Departamento de Ciências Biológicas, \\ Laboratório de Evolução e Diversidade Aquática (LEDA). Assis, SP, Brasil. \\ ${ }^{2}$ Universidade de São Paulo (USP), Instituto de Biociências (IB-USP), Departamento de Zoologia. São Paulo, SP, Brasil. \\ ${ }^{3}$ Universidade de São Paulo (USP), Centro de Biologia Marinha (CEBIMar). São Sebastião, SP, Brasil. \\ ${ }^{4}$ ORCID: http://orcid.org/0000-0002-9782-1619. E-mail: sergio.stampar@unesp.br \\ ${ }^{5}$ ORCID: http://orcid.org/0000-0002-7776-8793. E-mail: celinelopes@outlook.com \\ ${ }^{6}$ ORCID: http://orcid.org/0000-0002-4870-1119. E-mail: archangelis.stefany@gmail.com \\ ${ }^{7}$ ORCID: http://orcid.org/0000-0003-3747-8748. E-mail:acmorand@ib.usp.br
}

\begin{abstract}
The occurrence of /sarachnanthus Carlgren, 1924 (Cnidaria: Anthozoa: Ceriantharia) specimens in Cape Verde Islands is recorded. Identification of the tube anemone species Isarachnanthus maderensis (Johnson, 1861) was possible based on DNA Barcoding. A discussion on biogeographic patterns associated with ocean circulation and life cycle is presented.
\end{abstract}

Key-Words. Taxonomy; Biogeography; Marine Invertebrates.

\section{INTRODUCTION}

The genera Arachnanthus Carlgren, 1912 and Isarachnanthus Carlgren, 1924 (Cnidaria: Anthozoa: Ceriantharia) correspond to the only ones with described adult forms of the family Arachnactidae (den Hartog, 1977; Stampar et al., 2016). This family is distinguished from the family Cerianthidae (most of the currently valid species; cf. Stampar et al., 2016) mostly due to the presence of planktonic larvae with long prevalence in the water column (Stampar et al., 2015). This peculiarity of the life cycle resulted in complex biogeographic patterns, since the dispersion based on this larval type seems to be quite effective (Stampar et al., 2012, 2015). Recently, Stampar et al. (2012) demonstrated that the distribution pattern for the genus Isarachnanthus in the Atlantic maintains the gene flow due to marine currents. The finding of specimens at the Ascension Island (Stampar \& Morandini, 2017) demonstrated that the scenario proposed seems correct. However, the data available for the Eastern Atlantic records come from very distant areas, Madeira Island and Ascension Island (more than 4,500 km away). Thus, records in between those extreme regions are quite important to further test the scenario proposed. Consequently, this study presents occurrence data of the genus at the Cape Verde islands and discuss the relevance of biogeographic patterns based on life cycle aspects.

\section{MATERIAL AND METHODS}

Two specimens of Isarachnanthus (Fig. 1) were sampled by SCUBA diving during night time in Santo Antão Island, Porto Novo harbour, nine meters depth, 11 November 2014 (1) and Tarrafal, Santiago Island, 27 October 2015 (2). Each animal was directly preserved in Ethanol 95\%. These specimens were studied following the methods described by Stampar et al. $(2012,2014)$ and Rach et al. (2017). The barcoding region (COI) was sequenced using Folmer et al. (1994) primers (619 bp after assembly) (GenBank MK904564 and MK904565) and then compared with data of Stampar et al. (2012) and Stampar \& Morandini (2017). The voucher is deposited at Museu de Zoologia (USP) - MZUSP (MZSP 8468). P-distance model of base substitution was used to calculate genetic distances in MEGA7 software (Kumar et al., 2016). The maximum likelihood phylogenetic analysis was conducted via MEGA7 (500 replicates) with general time reversible model (GTR) (Kumar et al., 2016).

\section{RESULTS}

The sequences obtained were compared with the dataset available for the genus (after Stampar et al., 2012; Stampar \& Morandini, 2017). The first 


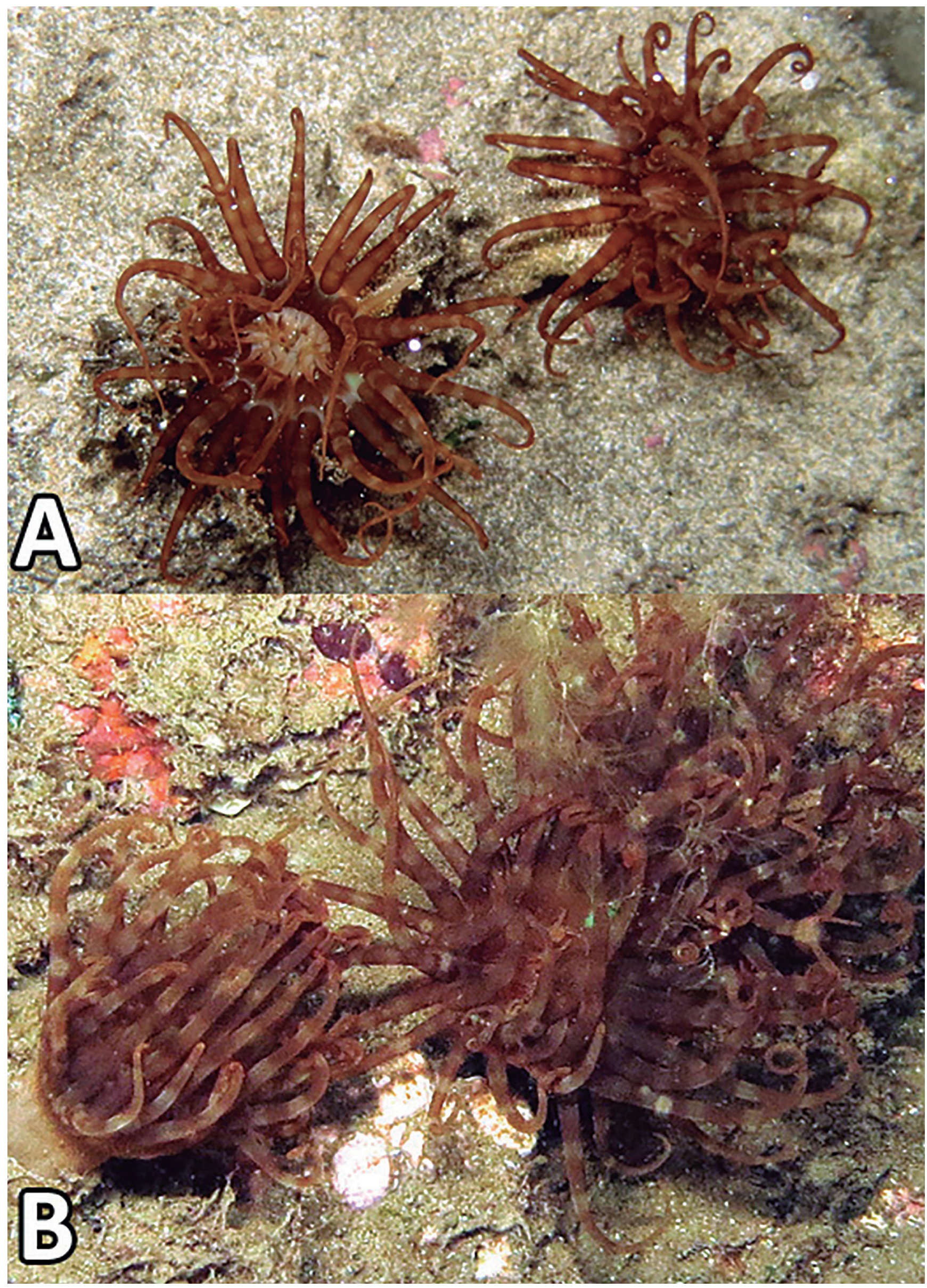

Figure 1. Specimens of /sarachnanthus maderensis (Johnson, 1861) in Santo Antão Island, Porto Novo harbor (A) and Tarrafal, Santiago Island (B). (Diameter around $3 \mathrm{~cm})$. Photos: Peter Wirtz. 
approach was a phylogenetic reconstruction by maximum likelihood, which indicated two monophyletic clades (Fig. 2). The specimens obtained from Cape Verde were clustered among the specimens delimited in the clade of the species /sarachnanthus maderensis (Johnson, 1861). The estimated genetic distance ( $p$-value) indicates that there is no variation in the DNA Barcoding sector between the Cape Verde, Madeira and Curaçao specimens (Table 1). At the same time, the variation for the Ascension Island specimens was not constant, for one specimen there was practically no variation, but for the other the variation was almost $8 \%$. The distance to the other species, Isarachnanthus nocturnus (Hartog, 1977), was always constant between 7 and $8 \%$. At the end, the DNA Barcode results indicate that the Cape Verdean specimens are Isarachnanthus maderensis.

\section{DISCUSSION}

This first record of the genus Isarachnanthus in Cape Verde based on molecular data is very relevant because it presents information from an area closer to the coast of the African continent. Stampar \& Morandini (2017) inferred that the coast line of the African continent should be inhabited only by the species Isarachnanthus maderensis, if the proposed evolutionary scenario is correct (Stampar et al., 2012). In this way, the present data maintain the 2012's proposal valid and still throw some light on the possible reproductive dynamics in this region. Some records have indicated the occurrence of Isarachnanthus nocturnus in the Eastern Atlantic (e.g., Bianchi et al., 2000), but results presented in this study and in Stampar \& Morandini (2017) indicate that this occurrence is not likely - further investigation on these specimens should be conducted both morphological and molecularly.

The distribution of the studied specimens from Cape Verde, Madeira and Curaçao (Fig. 3) are under the influence of the North Atlantic Gyre currents and this can be demonstrated by the absence of genetic distance between these individuals (Table 1). This same pattern can be recognized in the other species of Isarachnanthus on the coast of South America and the Caribbean, where

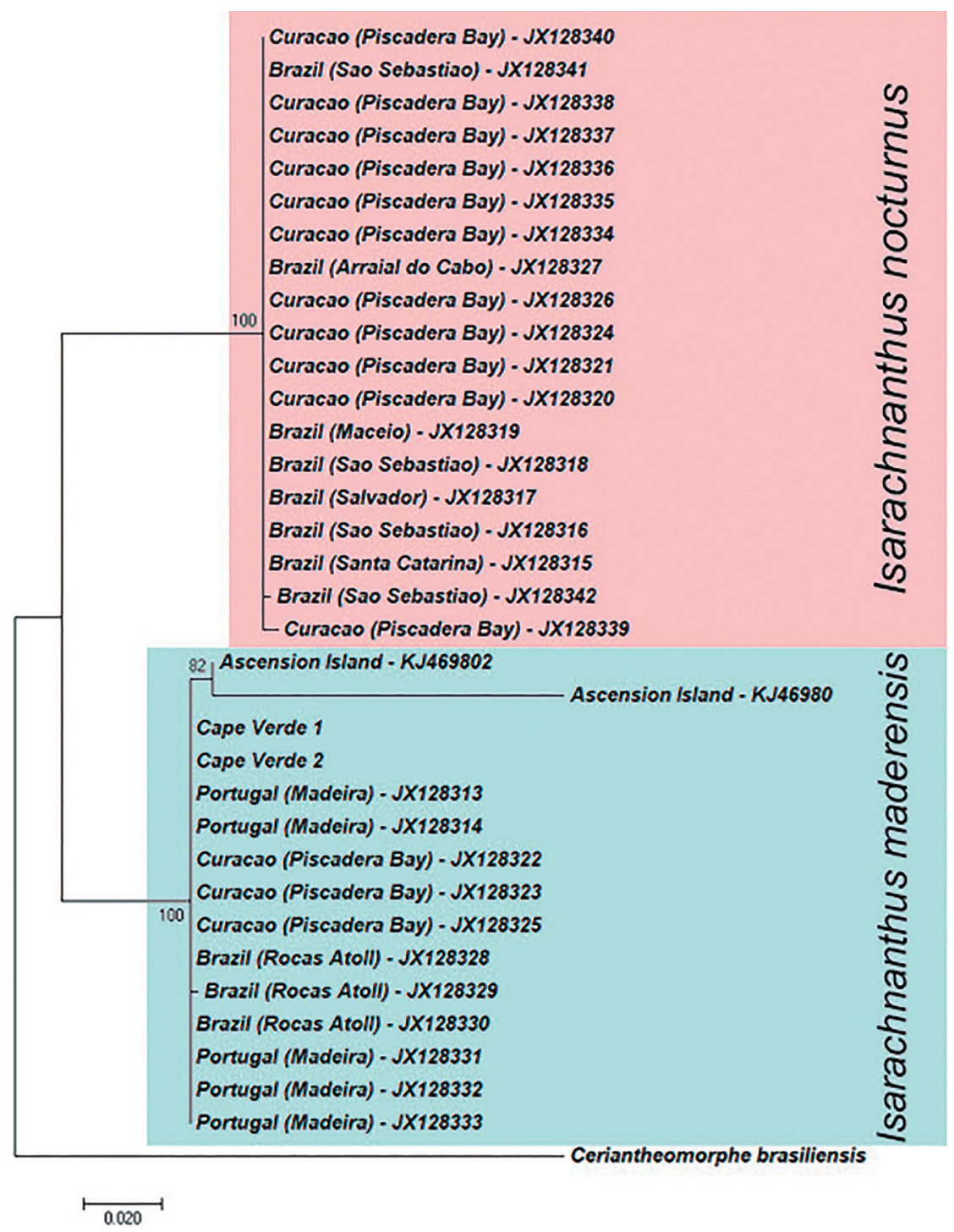

Figure 2. Evolutionary reconstruction of Isarachnanthus Carlgren, 1924 by Maximum Likelihood method based on the General Time Reversible model, likelihood $(-1410.7055)$ with 523 positions in the final dataset. 
Table 1. Estimates of evolutionary divergence ( $p$-distance) between Barcode sequences (COI) of /sarachnanthus from the Atlantic 0 cean.

\begin{tabular}{cccccc}
\hline & I. nocturnus & $\begin{array}{l}\text { I. maderensis } \\
\text { (Madeira) }\end{array}$ & $\begin{array}{l}\text { I. maderensis } \\
\text { (Rocas Atoll) }\end{array}$ & $\begin{array}{c}\text { I. maderensis } \\
\text { (Curaçao) }\end{array}$ & $\begin{array}{c}\text { I. maderensis } \\
\text { (Ascension Is.) }\end{array}$ \\
\hline Cape Verde & $0.07-0.08$ & 0.0 & $0.0-0.002$ & 0.0 & $0.006-0.08$ \\
\hline
\end{tabular}

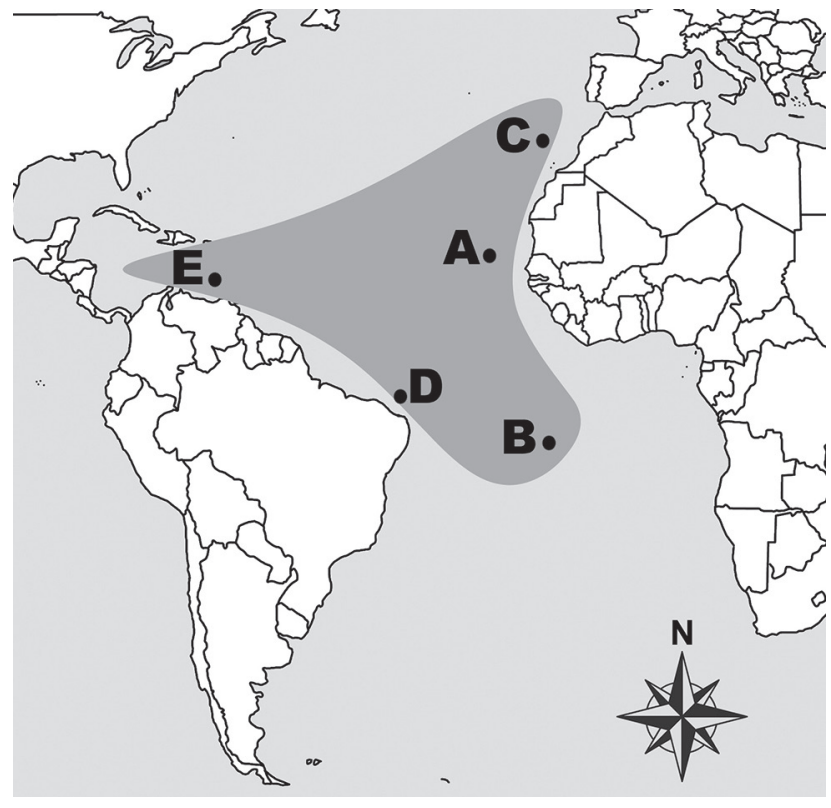

Figure 3. Area of occurrence of Isarachnanthus maderensis (Johnson, 1861), as follows: (A) Cape Verde (this study), (B) Ascension Island (Stampar \& Morandini 2017), (C) Madeira Island, (D) Rocas Atoll and (E) Curaçao (Stampar et al., 2012).

the specimens are under the influence of coastal currents from Argentina to the Caribbean Sea (Stampar et al., 2012). Both scenarios are maintained by the presence of a long-lived planktonic larva (Stampar et al., 2015) and the gene flow resulting from the action of these larvae is still very little known. Recently, an enormous phenotypic plasticity of the larvae has been discovered (Stampar et al., 2017), which can also have influence on these patterns. Still in this approach, it is possible to recognize a distinct genetic pattern in relation to the studied specimens of Isarachnanthus maderensis from Ascension Island and Rocas Atoll (Table 1). This different pattern must be the result of a partial biogeographic isolation, since these two areas are mainly under influence of the South Atlantic Gyre currents. The influence of marine currents on genetic structuring in the Atlantic Ocean is already known, including fairly similar areas and patterns (e.g., Muss et al., 2001). However, the possible greater isolation of the population of the Ascension Island deserves better attention, because at some level this can result in complete isolation (and eventually leading to speciation) in future.

\section{ACKNOWLEDGEMENTS}

This work was partly supported by São Paulo Research Foundation FAPESP 2015/24408-4, 2015/21007-9,
2016/50389-0, 2017/50028-0, CNPq 404121/2016-0, 304961/2016-7 and CAPES/CNPQ - PROTAX II 88882.156878/2016-01. CSSL is supported by São Paulo Research Foundation FAPESP 2016/04962-0. We would like to thank Dr. Peter Wirtz for the help in obtaining the specimens and Dr. Max Maronna for the help in molecular procedures and discussion.

\section{REFERENCES}

Bianchi, C.N.; Haroun, R.; Morri, C. \& Wirtz, P. 2000. The subtidal epibenthic communities off Puerto del Carmen (Lanzarote, Canary Islands). Proceedings of the 30 Symposium - Part A, Ponta Delgada Açores, 1998. Arquipélago, Life and Marine Sciences. Bulletin of the University of the Açores, Supplement, 02: 145-156.

Folmer, 0.; Black, M.; Hoeh, W.; Lutz, R. \& Vrijenhoek, R. 1994. DNA primers for amplification of mitochondrial cytochrome $\mathrm{c}$ oxidase subunit I from diverse metazoan invertebrates. Molecular Marine Biology \& Biotechnology, 3: 294-299.

den Hartog, J.C. 1977. Descriptions of two new Ceriantharia from the Caribbean region, Pachycerianthus curacaoensis n. sp. and Arachnanthus nocturnus $\mathrm{n}$. sp., with a discussion of the cnidom and of the classification of the Ceriantharia. Zoologische Mededelingen, 51(14): 211-242.

Kumar, S.; Stecher, G. \& Tamura, K. 2016. MEGA7: molecular evolutionary genetics analysis version 7.0 for bigger datasets. Molecular Biology and Evolution, 33(7): 1870-1874.

Muss, A.; Ross, R.D.; Stepien, C.A.; Wirtz, P. \& Bowen, B.W. 2001. Phylogeography of Ophioblennius: the role of ocean currents and geography in reef fish evolution. Evolution, 55(3): 561-572.

Rach, J.; Bergmann, T.; Paknia, 0.; DeSalle, R.; Schierwater, B. \& Hadrys, H. 2017. The marker choice: Unexpected resolving power of an unexplored C01 region for layered DNA barcoding approaches. PloS One, 12(4): e0174842.

Stampar, S.N. \& Morandini, A.C. 2017. Occurrence of /sarachnanthus (Cnidaria: Anthozoa: (eriantharia) at Ascension Island: a test of hypothesis. Journal of the Marine Biological Association of the United Kingdom, 97(4): 689-693.

Stampar, S.N.; Maronna, M.M.; Vermeij, M.J.; Silveira, F.L. \& Morandini, A.C. 2012. Evolutionary diversification of banded tube-dwelling anemones (Cnidaria; Ceriantharia; Isarachnanthus) in the Atlantic Ocean. PLoS One, 7(7): e41091.

Stampar, S.N.; Maronna, M.M.; Kitahara, M.V.; Reimer, J.D. \& Morandini, A.C. 2014. Fast-evolving mitochondrial DNA in Ceriantharia: a reflection of Hexacorallia paraphyly? PLoS One, 9(1): e86612.

Stampar, S.N.; Morandini, A.C.; Branco, L.C.; Silveira, F.L. \& Migotto, A.E. 2015. Drifting in the oceans: Isarachnanthus nocturnus (Cnidaria, Ceriantharia, Arachnactidae), an anthozoan with an extended planktonic stage. Marine Biology, 162(11): 2161-2169.

Stampar, S.N.; Maronna, M.M.; Kitahara, M.V.; Reimer, J.D.; Beneti, J.S. \& Morandini, A.C. 2016. Ceriantharia in current systematics: life cycles, morphology and genetics. In: Goffredo, S. \& Dubinsky, Z. (Eds.). The Cnidaria, past, present and future. Cham, Springer. p. 61-72.

Stampar, S.N.; Maronna, M.M.; Kitahara, M.V.; Angelis, S.A.; Lopes, C.S.; Reimer, J.D.; Morandini, A.C. \& Migotto, A.E. 2017. DNA barcodes unlocking the phenotypic plasticity in adult and larvae: a case study in Ceriantharia (Cnidaria, Anthozoa). Genome, 60(11): 998. (Scientific abstracts from the $7^{\circ}$ International Barcode of Life Conference. http:// doi.org/10.1139/gen-2017-0178). 